\title{
Europe in the new global economic governance: can we still make a difference?
}

\author{
Marco Buti ${ }^{1}$
}

Published online: 29 June 2016

(C) European Union 2016

\section{Introduction}

Global economic governance is undergoing dramatic changes. In the long term, it is expected that differential growth rates, combined with demographic developments, will shift global economic power from advanced to emerging and developing countries. The global financial crisis has accelerated this development. While in 1999 emerging and developing economies collectively accounted for $42 \%$ of global GDP on a purchasing power parity basis, by 2014, they held $55 \%$, and this is

This editorial is based on the speech delivered at Accademia Nazionale dei Lincei, Rome, on the 10 of March 2016 by Marco Buti, Director General for Economic and Financial Affairs at the European Commission. The information and views set out in this article are those of the author and do not necessarily reflect the official opinion of the European Commission. The author would like to thank Heinz Scherrer and Dries Belet for useful discussions and input in preparing this article.

Marco Buti

marco.buti@ec.europa.eu

1 European Commission, Brussels, Belgium 
expected to rise further to $61 \%$ by $2020 .{ }^{1}$ Against the background of an increasingly integrated global economy and important shifts in global economic weights, the effective governance of the world economy is becoming ever more important.

Long-term trends in global economic governance are clear when looking at the evolution of the international monetary system. Historically, international monetary relations in the post-WWII era were governed by the Bretton Woods system. Its essential feature was a fixed exchange rate of all currencies vis-à-vis the US dollar, which reinforced the central role of the dollar in global governance. In the 1960s, the Bretton Woods system came under pressure, as the US dollar's fixed value against gold was seen as overvalued due to the rising US current account deficit. The system dissolved between 1968 and 1973, and the major currencies commenced floating against each other permanently. Global economic governance has in recent decades evolved towards a more multipolar system. Monetary relations are no longer solely centred on the US dollar, but instead are built on several pillars, including the euro, the yen, the pound sterling, and a renminbi, which is growing in significance. The increasing role of the renminbi demonstrates the rise of emerging markets and developing countries in the international economy.

The greater economic weight of emerging and developing countries means that they expect an increased role in global governance. The challenge will be to further open up the existing system to include the 'newcomers' in an appropriate way.

Reforming global economic governance became unavoidable after the global financial crisis, which had profound systemic consequences. At the economic level, the crisis made clear the extent of global interdependence and spillovers. This meant that at the political and institutional level, the appropriate response was to step up international cooperation, resulting in the emergence of the $\mathrm{G} 20$ as a new forum for the coordination of economic policy.

These changes affect the role and position of Europe in the world. The EU remains a key partner in the new global order. Depending on the measure, the EU accounts for $17 \%$ (GDP based on PPP) or $24 \%$ (GDP in nominal terms) of the global economy. The EU is also the world's largest trading block and a leader in international investment. The central question is how to position the EU in a postcrisis world, and how we manage to punch according to our weight in the global economy.

In what follows, I argue that in order to remain a leader in global economic governance, Europe will need to face up to a number of mainly domestic challenges, while at the same time making use of and enhancing its existing strengths.

\section{Impact of the financial and economic crisis on global governance}

The financial crisis that broke out in 2008 demonstrated the high degree of global interdependence and the importance of effective global economic governance. The crisis especially underlined that (1) spillovers can be rapidly transmitted via

\footnotetext{
1 See Mohan and Kapur (2015).
} 
financial markets with a strong systemic impact; (2) financial capital flows and monetary policies can have a global dimension; and (3) international cooperation is needed to achieve mutually beneficial outcomes and positive externalities, while avoiding zero-sum economic policies.

First, spillovers transmitted via financial markets can have dramatic consequences, both regionally and globally. The high degree of global financial integration in recent decades can be seen in the rising amount of external assets and liabilities. This has created both benefits and risks to the global system. Aside from the traditional real economy channel, global spillovers can spread through financial transmission channels including changes in interest rates, risk premiums and asset prices, as well as through investor confidence effects and changes in the composition of asset holdings.

The creation of the European Economic and Monetary Union (EMU) has led to a high level of economic interdependence among euro area countries, magnifying the spillovers of domestic policies and vulnerabilities. As a result, the debt crisis in some European countries had a direct impact on other economies in Europe and beyond. The EU had to act timely to avoid a further contagion effects towards other countries. More recently, as a further demonstration of the high degree of global economic and financial interconnectedness, Chinese rebalancing, financial market risks, and monetary policy uncertainties have led to global spillovers materializing through increased financial market volatility.

Second, financial capital flows and monetary policy were shown to have a global dimension. Until recently, international macroeconomics postulated the "financial trilemma": free capital mobility, independent monetary policies and fixed exchange rates cannot all be pursued at the same time. EMU solved the trilemma by "communitarising" monetary policies while leaving the exchange rate of the euro to fluctuate freely. At the global level, the comforting conclusion was that free capital mobility and monetary policies targeting domestic objectives were possible, provided that exchange rates remained flexible. However, Helene Rey has argued ${ }^{2}$ convincingly that widespread co-movement in capital flows, asset prices, and credit growth across countries-a global financial cycle-makes the trilemma moot. Flexible exchange rates do not insulate national economies in a world of free capital movements. This transforms the "trilemma" into a "dilemma": independent monetary policies are possible only if the capital account is managed. The manifestation of this new dilemma is the currency war risk highlighted by Brazilian Finance Minister Guido Mantega in 2010, when capital flowed massively from advanced economies to emerging market economies as a reaction to the financial crisis.

Third, the current international economic system is marked by a high degree of openness. It underpins the global economy by enabling the free flow of trade and capital, which has facilitated a rapid expansion in world output and a shift in relative economic power since the Second World War. In order to preserve this system in a post-crisis world, it is essential to ensure close cooperation between policy makers so that all economies benefit from the positive spillovers of the open system in areas

\footnotetext{
${ }^{2}$ See Rey $(2013 a, b)$.
} 
such as macroeconomic policy, financial regulation, taxation transparency, and trade and investment. Cooperation is also crucial to avoid zero-sum beggar-thyneighbour policies-where one country attempts to remedy its economic problems by means that tend to worsen the economic situation of another, for instance by putting up trade barriers.

Another important example of this is the temptation of using monetary policy to depreciate one's own currency to obtain a competitive advantage.

Domestic monetary policy responses to the crisis, such as Quantitative Easing, also have generated spillover concerns, as has the gradual normalisation of monetary policy. In a highly integrated financial world with cross-country linkages, there is a need for cooperation in order to mitigate the negative externalities of domestic policies and to ensure external stability.

\section{Institutional changes following the financial crisis: the rise of the G20}

The new degree of economic and financial interconnectivity and the sudden awareness of the acute global risks brought to the fore by the financial crisis, had consequences at the institutional level. In particular, a number of global institutional innovations took place to address the challenges that arose due to the crisis. For instance, the G20 was elevated from a Finance Ministers' group to the level of Heads of State and Government; the Financial Stability Board (FSB) was created; and the G20 decided to triple the resources of the International Monetary Fund (IMF).

The perception of the relative weakness of advanced economies following the crisis also boosted the confidence of emerging market economies. Emerging and developing economies called for faster reform of global economic institutions such as the IMF and World Bank, arguing that changes in relative economic weights should be reflected in the structures of international governance.

The G20 is a prime example of recent policymaking in global economic governance. At the 2009 G20 Pittsburgh Summit, the group was designated the premier forum for international economic and financial cooperation. The G20 has emerged as an informal group that promotes cooperation between advanced and emerging-market countries on key challenges related to global economic growth and stability. It represents almost $90 \%$ of global GDP, two-thirds of the world's population, and $80 \%$ of world trade.

The G20 has proven an effective forum for bringing advanced and emerging economies around the table to find consensus and create political momentum in order to strengthen global governance. It has demonstrated that it can take swift and decisive action when dealing with the global financial crisis in 2008-2009. In addition, by bringing together different centres of economic power, the G20 has helped to increase trust between advanced economies and emerging markets for the benefit of all.

\subsection{Key achievements of the G20}

Since its elevation to Leaders' level, the G20 has had a number of important achievements. 
First, and most importantly, when the global crisis broke out in 2008-2009, the G20 managed to avoid another great depression like in the early 1930s, through a coordinated and decisive G20 response to the global recession and the stabilisation of the financial system. The summits in Washington (November 2008), London (April 2009) and Pittsburgh (September 2009) focused on three key issues: (1) macroeconomic stimulus to avoid a 1930s-style depression; (2) the tripling of the financial resources of the IMF to strengthen global firewalls and support countries under financial stress because of the crisis; and (3) reforms to stabilise financial markets in order to avoid a collapse, and to strengthen regulatory and supervisory regimes so as to avoid future crises. In addition, the G20 also committed to refrain from protectionism and roll back restrictive trade and investment measures.

Second, at the Seoul Summit (November 2010), G20 Leaders' most important decision was to finalise the IMF quota and governance reform. This included a doubling of the permanent quota of the IMF, a significant $(6.40 \%)$ shift of IMF shares to emerging market and developing countries, and greater representation for emerging market and developing countries at the IMF Executive Board through the transfer of two seats from European countries. While some steps have been accomplished, the latter condition remains to be delivered, as there is no agreement on how to share the burden of adjustment amongst European countries.

Third, in St Petersburg in September 2013, the G20 decided to address Base Erosion and Profit Shifting, tackle tax avoidance, and promote tax transparency and automatic exchange of tax information.

Finally, at the G20 Brisbane Summit in November 2014, the G20 put forward structural reform measures and growth strategies to meet the ambitious goal of lifting its collective GDP by more than $2 \%$ over 5 years.

\subsection{Can the G20 win the peace?}

Going forward, in order to remain effective, the G20 needs to overcome a number of challenges. ${ }^{3}$ First, to stay relevant, the G20 needs to evolve from acting as a shortterm crisis response committee to addressing more long-term challenges for the global economy. In other words, the G20 should shift its focus from "winning the war"-i.e. responding to the 2008 crisis to avoid the meltdown of the global financial system - to "winning the peace", i.e. overcoming the legacy of the crisis (notably high public and private debt levels and low potential growth) and creating the conditions for strong, sustainable and balanced growth.

Second, to guarantee the G20's credibility and effectiveness, it is essential that G20 members implement their existing G20 commitments, for instance on financial regulatory reform or on international tax transparency. Consistent monitoring will be key to ensure the effectiveness of reforms as well as a global level playing field.

Third and finally, given its diverse membership, the G20 will need to show leadership to identify points of common interest and further explore new topics for cooperation, such as, for example, anti-terrorism financing or green financing.

\footnotetext{
3 See Bertoldi et al. (2016).
} 
Looking at this year, the fact that China in 2016 has taken up the rotating annual G20 Presidency comes at a key point in time. The Chinese Presidency is in itself significant, since it symbolises China's more outward-looking role in global economic governance. An important milestone in this regard was the recent inclusion of the renminbi into the IMF's Special Drawing Rights (SDR) currency reserve basket. China's presidency should also facilitate a better integration of a number of new institutions and initiatives in the international system, such as the Asian Infrastructure Investment Bank (AIIB) and the New Development Bank (NDB), a multilateral development bank operated by the BRICS states and headquartered in Shanghai.

\section{How can the EU make a difference in global economic governance}

The EU faces a strong test of its capability to remain a leading voice in global economic governance. We will need to rise up to continued challenges in global economic governance, in particular by overcoming a number of weaknesses as well as by leveraging and enhancing our existing strengths.

\subsection{Overcoming weaknesses}

First, projecting strength externally requires internal strength, which means that a higher degree of internal EU cohesion is needed. In particular, therefore, the EU must complete the single market and become a genuine Economic and Monetary Union-including through a stronger economic and fiscal governance framework and a fully working Banking Union. The Five Presidents' Report indicates the frontier to strengthen EU integration by complementing Banking Union with a Fiscal, Economic and ultimately Political Union. This domestic agenda was complemented in October 2015 with a European Commission proposal to EU Member States on strengthening the external representation of the euro area in the International Monetary Fund. ${ }^{4}$ This proposal suggested a transition to a single seat for the euro area in the Fund by 2025. A unified representation of EMU with a single voice at the IMF would be an important step forward for the euro area to speak more effectively and credibly at the international level.

Second, to play an effective role on the global stage, Europe needs to overcome its "small country syndrome". In a global perspective, the EU consists of small and medium-sized countries; however, even the largest EU Member States behave like small countries. Many EU Member States, for historical reasons or otherwise, tend to focus almost exclusively on domestic objectives and are not ready to take up broader responsibilities. Worse, they tend to see the EU and the euro area as a simple collection of Member States, with the consequence that the whole area suffers from the small country syndrome. Consequently, the EU often does not take an effective stance on par with other major global powers such as the United States

\footnotetext{
${ }^{4}$ See European Commission (2015a, b).
} 
or China. Europe needs to act as a large policy entity in order to be an effective global actor in the twenty-first century.

Third, the political phenomenon of the small country syndrome also has an economic counterpart, namely the "reverse credit paradox". Historically, going back to the Bretton Woods system and earlier in international economic relations, creditors were in a comparatively stronger position vis-à-vis the weaker position traditionally held by debtor countries. As a result, creditors were generally in a better position than debtors to achieve their political and economic interests in the international system. However, this asymmetry has recently reversed, and the euro area is now at risk of the "reverse credit paradox". The euro area as a whole runs a large and persistent current account surplus. This is no longer seen as a strength but rather as a sign of economic weakness and a source of political vulnerability. It exposes the euro area to criticisms such as not contributing to global growth and demand, and exporting deflation. This is particularly the case as emerging market economies are not in the position to carry the global economy on their shoulders alone.

Finally, and related to the previous point, the EU is currently subject to the risk of attracting criticism from multiple sides, namely from the United States-for not assuming its responsibility to boost global growth-and at the same time from emerging markets, for not acknowledging the shifts of relative power in the global economic system. ${ }^{5}$ A strong and convincing response will be needed to address these criticisms.

\subsection{Leveraging strengths}

The other crucial precondition for the EU to play an effective role in global governance is that it should make effective use of its existing strengths. This entails leveraging the attractive aspects of the European model to enhance the soft power of the EU.

The EU is strongly committed to effective multilateralism, the EU continuously stands ready to work with our international partners on multilateral, win-win solutions. Our social and environmental models are examples for non-EU countries. Social systems in the EU combine equality and growth. This makes the European model more attractive for some of our international partners than other models such as the social system of the United States. Also, the European environmental model forms another significant strength. The EU has been at the forefront on many global environmental challenges and on the fight against climate change. Importantly, the EU was a driving force in reaching the first universal, legally binding global climate deal at the Paris COP21 conference in December 2015. Finally, the EU also represents an attractive model for regional integration and cooperation. The postWWII historical experience of peaceful cooperation in the EU is a powerful example for countries and regions seeking closer integration and effective crossborder cooperation. During the euro area crisis, due to the sovereign debt crisis, several G20 partners emphasised that they saw the integration achieved in the euro

\footnotetext{
${ }^{5}$ Cfr. Footnote 4.
} 
area as an "important global public good" that needed to be preserved. In addition, the European experience with coordinating economic policies among Member States has inspired a similar model of coordination in the G20, namely through the growth strategies process. In all, provided that it tackles its domestic challenges, Europe has significant strengths that should be leveraged to increase its influence in global economic governance.

\section{Conclusion}

Global economic governance in recent decades has moved towards a more multipolar system, increasingly reflecting the shift in global economic weights due to demographic developments, changes in growth dynamics, and shifting trade patterns. This has been accelerated by the global financial crisis and the perceived weakness of advanced economies in responding to it. These developments have contributed to a call for an increased role for emerging markets in global governance.

The financial crisis has also lead to a recognition of the need for more coordinated economic governance, able to respond to the challenges posed by the crisis, such as the consequences of financial spillovers and the management of the international monetary system. This has led to institutional innovations, in particular the rise of the $\mathrm{G} 20$.

There is clearly a benefit to be had from global economic policy coordination and the EU has a lot to offer in this respect. However, in order to do so, the current question for the EU is how to maintain and promote Europe's position in the postcrisis world, characterised by the rise of emerging powers. The EU will need to address its weaknesses, but also leverage its strengths.

In particular, the EU (and the euro area) should find a common narrative on the domestic economic governance agenda and on the way forward. It should enhance its internal cohesion to project external strength. In order to do so, the EU needs to act within the framework of a new politically consistent triangle, which entails challenges at the Member State, EU and global level. First, at the Member State level, national governments need to build a positive narrative on European integration, so that citizens get involved in and understand European decision making and that sharing national sovereignty on certain matters leverages power, not reduces it. Second, at the EU level, there is the need to overcome intergovernmental coordination and move towards a more integrated European political system. By achieving a strong and stable internal system, the EU would be able to project its strength externally. Finally, at the global level, the EU needs to have a stronger and unified voice on political and economic matters. Overcoming the fragmentation of external representation and speaking with a single voice would decisively increase the international influence of the EU. 


\section{References}

Bertoldi, M., Scherrer, H., Stanoeva, G. (2016). The G20 and the EU: A win-win game, ECFIN Economic Brief 10, March 2016, European Commission.

European Commission (2015a). Communication from the Commission to the European Parliament, the Council and the European Central Bank-a roadmap for moving towards a more consistent external representation of the euro area in international fora, $\operatorname{COM(2015)} 602$ final.

European Commission (2015b). Proposal for a Council Decision laying down measures in view of progressively establishing unified representation of the euro area in the International Monetary Fund, COM (2015) 603 final from 21 October 2015.

Mohan, R., Kapur, M. (2015). IMF working paper-emerging powers and global governance: Whither the IMF?

Rey, H. (2013a). Dilemma not trilemma: The global financial cycle and monetary policy independence. Paper presented at the Jackson Hole Symposium, August.

Rey, H. (2013b). Dilemma not trilemma: The global financial cycle and monetary policy independence. VoxEU.org, 31 August. 